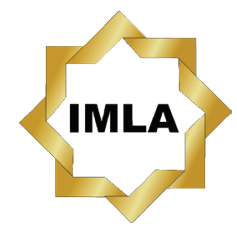

\title{
LAFAZH DAN MAKNA DALAM PERSPEKTIF PEMIKIRAN LINGUISTIK IBN JINNI
}

\author{
Wati Susiawati \\ Universitas Islam Negeri Syarif Hidayatullah Jakarta \\ e-mail : wati.susilawati@uinjkt.ac.id
}

Naskah diterima: 18 September 2015, direvisi: 12 Oktober 2015, disetujui: 20 Nopember 2015.

\begin{abstract}
Based on the readings and content analysis (tahlîl al-muhtawa) of Ibn Jinni's book, al-khashâ'ish and the other works related to linguistic thought, it was found that the notion of linguistic Ibn Jinni about the utterances and meaning are in the area of macro-linguistics that can not be separated from the study of phonology, morphology, syntax, and semantic. In addition, it cannot be separated from one another, utterances and meaning in Arabic, according to Ibn Jinni, it is used and developed as a medium of communication, both spoken and written. Therefore, word and meaning must be understood in the process, the events and the context of linguistic and socio-cultural context as a whole. Word and meaning of the object of study is the linguistic multiperspective, thus giving birth to the various fields of linguistic science. Linguistic thought about the word and meaning is important not only serve as a theoretical basis for understanding the text in Arabic, but also significantly to the development of learning 'ilm al-dalâlah (semantics) to the Arabic leaner or scholar.
\end{abstract}

Keywords : phonology, morphology, sintax, synonim

\section{Abstrak}

Berdasarkan pembacaan dan analisis isi (tahlîl al-muhtawa) terhadap buku al-khashâ'ish karya Ibn Jinni dan karya-karya penunjang lainnya, ditemukan bahwa pemikiran linguistik Ibn Jinni tentang lafazh dan makna berada dalam spektrum makro linguistik yang tidak dapat dipisahkan dari kajian fonologi, morfologi, sintaksis, dan semantik. Selain tidak dapat dipisahkan satu sama lain, lafazh dan makna dalam bahasa Arab, menurut Ibn Jinni, digunakan dan dikembangkan sebagai media komunikasi, baik lisan maupun tulisan. Karena itu, lafazh dan makna harus dipahami dalam proses, peristiwa dan konteks kebahasaan maupun kontek sosial budaya secara menyeluruh. Lafazh dan makna merupakan objek kajian linguistik yang multiperspektif, sehingga melahirkan berbagai bidang ilmu kebahasaan. Pemikiran linguistik tentang lafazh dan makna tidak hanya penting dijadikan sebagai landasan teori dalam memahami teks bahasa Arab, tetapi juga signifikan untuk pengembangan pembelajaran 'ilm al-dalâlah bagi pengkaji atau sarjana bahasa Arab.

Kata Kunci : fonologi, morfologi, sintaksis, sinonim

How to Cite : Susiawati, Wati. "LAFAZH DAN MAKNA DALAM PERSPEKTIF PEMIKIRAN LINGUISTIK IBN JINNI" Arabiyat : Jurnal Pendidikan Bahasa Arab dan Kebahasaaraban [Online], Vol. 2 No. 2 (31 Desember 2015)

Permalink/DOI: http://dx.doi.org/10.15408/a.v2i2.2133 


\section{Pendahuluan}

Semantik merupakan salah satu disiplin ilmu yang lebih menitikberatkan kajiannya pada bidang makna dengan berpangkal pada acuan dan symbol. Ilmu ini menitikberatkan pada kajian makna baik berupa lambang-lambang atau tanda-tanda yang menyatakan suatu makna, hubungan makna yang satu dengan yang lain serta pengaruhnya terhadap manusia dan masyarakat ${ }^{1}$. Semantik, fonologi, morfologi, dan sintaksis merupakan cabang-cabang linguistik. Semantik dalam bahasa Arab disebut 'ilm al-dalâlah ${ }^{2}$.

Ibn Jinniadalah salah seorang ahlibahasa Arab yang terkenal dengan pandanganpandangannya tentang kebahasaan, khususnya bahasa Arab, yang dituangkan dalam sebagain besar karyanya. Diantara pandangannya tersebut adalah teori tentang makna dan lafazh yang dibahas dalam bukunya, al-Khashâ'ish. Buku ini menjadi rujukan utama tulisan ini di samping buku al-Dalâlah al-Lugawiyah 'ind al-'Araba karya Mujahid.

Dalam pembahasan ini, akan dikemukakan juga pandangan-pandangan seorang linguis asal Inggris J.R Firth ( 1890$1960)^{3}$ yang oleh mayoritas pemerhati ilmu bahasa Barat dianggap sebagai pioneer dalam bidang ini, padahal dalam kenyataannya Ibn Jinni jauh sebelumnya sudah mengemukakan kerangka dasar teori. Tidaklah berlebihan, jika dikatakan bahwa teori kebahasaan tentang lafazh dan makna yang dikenal sekarang adalah sebagai teori Ibn Jinni yang sudah disempurnakan dan dikemas secara sistematis sehingga

\footnotetext{
1 Henry Guntur Tarigan, Pengajaran Semantik, (Bandung: Angkasa, 1995), Cet. Ke- 3, h. 7

2 T. Fatimah Djajasudarma, Semantik 1: Pengantar ke Arah Ilmu Makna, (Bandung: Erasco, 1993), Cet. Ke-1, h. 1

Harimurti Kridalaksana. Kamus Linguistik (Jakarta: Gramedia, 1993) h. 55.
}

memenuhi persyaratan keilmiahan sebuah bidang studi oleh Firth . Namun sebelumnya, penulis bermaksud membahas tentang biografi Ibn Jinni secara ringkas dan karyakaryanya sebagai penguat argumen bahwa Ibn Jinni-lah yang lebih pantas menyandang gelar sebagai pioneer teori makna dan lafazh.

\section{Biografi Intelektual Ibnu Jinni}

Ada beberapa pendapat tentang tahun kelahiran Ibnu Jinni yang bernama lengkap Abu Fatah Utsman Ibn Jinni alMawsûly al-Nahwy. ${ }^{4}$ Menurut Muhammad 'Ali Najjar dalam pengantar al-Khashâ'aish, Ibn Jinni dilahirkan sebelum tahun 330 H. Sementara Abu al-Farra' menyebutkan tahun 302 H sebagai tahun kelahiran Ibn Jinni. Sedangkan Ibn Qadhi Shuhbah dalam bukunya, "Mawsû'ah Abâqirat al-Islâm" menyatakan bahwa Ibn Jinni wafat pada tahun $392 \mathrm{H}$ dalam usia 70 tahun. Bila pendapat ini dipedomani sebagai acuan, maka diperkirakan tahun kelahiran Ibn Jinni pada tahun 321/322 H. Adapun tentang tempat kelahirannya tidak ada perbedaan pendapat, yakni di Mosul, Irak Utara.

Dari segai silsilahnya, Ibn Jinni itu keturunan seorang Romawi dan Yunani yang menjadi pembantu Sulaiman bin Fahd bin A $\underline{h}$ mad al-Azdî, akan tetapi tidak ada keterangan tentang kapan ayahnya datang ke Mosul atau tentang profesi majikannya. Mungkin karena statusnya sebagai pembantu atau agar diterima dengan baik di kalangan masyarakat Arab. Ibn Jinni menisbatkan namanya kepada kabilah majikannya setelah nama ayahnya, yakni Abu Fattah Utsman Ibn Jinni al-Azdî.

\footnotetext{
4 Ibnu Burhan Al-'Ukbary, Syarhu Al-Luma', (Kuwait: Silsilat al-Turatsiyyah, 1404 H/1994 M.) Cet.I. Bagian I, h. 43.; Ibnu Jinni, Al-Khashâ'ish 1-3. (Kairo: Matba'ah Dâr al-Kitâb al-Mishriyah, 1371 H/ 1952 M). Tahqîq: Muhammad 'Ali Najjâr)
} 
Sementara Ibn Ma'kula mendengar dari Isma'il bin Mu'ammal bahwa Ibn Jinni berasal dari gennaius ${ }^{5}$ yang berarti: "mulia, jenius, baik pikirannya dan ikhlas" pertanda bahwa ayahnya seorang yang terhormat, dan karena itu pula memakai nama Ibn Jinni.

Ibn Jinni dibesarkan di Mosul, tempat memulai pelajarannya dalam berbagai dasar disiplin ilmu dari ulama yang berbeda. Ilmu Nahwu dipelajarinya dari Abu 'Ali al-Hasan bin Ahmad bin 'Abd al-Ghaffâr bin Sulaiman al-Fârisi al-Baghdâdi. Selain itu Ibnu Jinni juga belajar sastra pada Abu Bakar Muhammad bin al-Hasan al-Ru'yani, Abu Bakar al-Sijistaniy, Muhammad bin Salmah dan Abu 'Abbas al-Mubarrid. Adapaun i'râb dipelajarinya dari fushâha Arab, sebut misalnya Abu 'Abdillah Muhammad bin Assaf al-'Aqliy atau Abu 'Abdillah al-Shajariy. Untuk memuaskan dahaganya akan ilmu, Ibn Jinni tidak segan-segan berjalan jauh sampai ke Iraq, Suriah, dan lain-lain.

Ibn Jinni menghabiskan masa kanakkanaknya juga di kota kelahirannya tersebut. Di Mosul juga ia mendapatkan pendidikan dasarnya, belajar ilmu nahwu pada gurunya yang bernama Ahmad bin Muhammad alMausili al-Syafi'i yang lebih dikenal dengan sebutan al-Akhfasy. Setelah itu, ia pindah ke Baghdad dan menetap di sana. Di kota ini, ia mendalami linguistik selama kurang lebih empat puluh tahun pada gurunya, Abu 'Ali al-Farisi. ${ }^{6}$ Begitu lamanya Ibn Jinni menimba pengetahuan bahasa pada Abu 'Ali, sehingga keduanya terjalin hubungan yang sangat erat seperti hubungan persahabatan.

Selain berguru secara khusus kepada Abu 'Ali, Ibn Jinni juga banyak belajar pada

${ }^{5}$ Rihab Khadar 'Ikâwiy, Mausu'ah Abaqirah AlIslamfi al-Nahwi wa al-lughah wa al-Fiqh, (Beirut:), h. 97 lihat juga Ibnu Jinni, Al-khashaish (Beirut: Dar al-Kitab al-Arabi, 1983), jilid 1, h. 8. 8.

${ }^{6}$ Abdul Halim al-Najjar, Târikh al-Adab al-Arabiy, Jilid II, (Kairo: Dâr al-Ma'ârif, tt), h. 244 tokoh linguistik lain, terutama yang terkait dengan pengambilan sumber bahasa (ruwât al-lughah wa al-adab), di antara mereka ialah Abu Bakr Muhammad bin alHasan yang lebih dikenal dengan sebutan Ibn Miqsam, seorang pakar qirâ'at alQur'an, Abu Abdillah Muhammad bin al'Assaf al-'Uqaili al-Tamimi, terkadang Ibnu Jinni menyebutnya dengan Abu Abdillah alSyajari.

Ibn Jinni hidup pada abad keempat hijriah (abad X M) yang merupakan puncak perkembangan dan kematangan ilmuilmu keislaman, yang pada umumnya para ilmuawan pada abad ini tidak saja menguasai satu disiplin pengetahuan, tetapi juga menguasai disiplin-disiplin lainnya. Oleh karena itu, tidak berlebihan jika para penulis biografi Ibn Jinni menyatakan bahwa karyakarya tokoh yang satu ini menggabungkan teori linguistik, teori prinsip fiqh (ushûl fiqh), juga teori ilmu kalâm (teologi) karena dia penganut mazhab Mu'tazilah, mazhab yang juga dianut oleh guru besarnya, Abu Ali al-Farisi. ${ }^{7}$ Ibn Jinni menetap di Baghdad hingga wafat pada tahun $392 \mathrm{H}^{8}$

Baik ulama sezamannya, maupun generasi para linguis sesudahnya, mengakui penguasaan dan keluasan pengetahuan Ibn Jinni atas linguistik Arab. Abu Tayyib alMutanabbi (w. $354 \mathrm{H}$ ), penyair yang sangat terkenal dan sahabat Ibn Jinni, misalnya, pernah berkomentar tentang Ibn Jinni, “Dia adalah sosok yang kehebatannya belum diketahui oleh banyak orang". Bahkan, apabila al-Mutanabbi ditanya tentang makna suatu kata yang ia ucapkan (dalam

\footnotetext{
Abdillah, Zamzam Afandi. Ibn Jinni Menembus Sekat Mazhab Linguistik dalam Adabiyyat. Vol. 8. 2009, h. 54. Lihat juga Abd al-Halim an-Najjar, Târikh al-Adab alArabi, h. 244.

8 Rihab Khadar 'Ikâwiy, Mausu'ah Abaqirah Al-Islam fi al-Nahwi wa al-lughah wa al-Fiqh, (Beirut: tp), h. 100.
} 
puisinya), atau tanda harakat (i'râb) yang dianggap aneh, dia selalu menjawab, "Tanyakanlah pada syaikh juling, Ibn Jinni, dia akan menjawab semuanya". Demikian pula Ahmad bin Mustafa, dalam bukunya, Miftâh al-Sa'âdah, menyatakan bahwa Ibn Jinni adalah intelektual yang sangat cerdas, memiliki pengetahuan yang luas dan mendalam di bidang nahwu dan sharaf. Ibn Jinni adalah linguis yang prolifik dan produktif. Ini dibuktikan dengan berbagai karyanya. ${ }^{9}$

Di antara sekian banyak gurunya, Ibn Jinni paling dekat dengan dan paling menghormati Abu 'Ali al-Farisi. Dia tidak pernah menentangnya bahkan sering mengemukakan pendapat al-Farisi sebagai rujukan dalam buku-bukunya. Perkenalannya denga al-Farisi dimulai ketika Ibn Jinni menanyakan tentang perubahan huruf g (waw) menjadi I (alif) pada katakata قام karena pada saat itu hari sudah sore maka al-Farisi tidak menjawab pertanyaan Ibn Jinni. Baru keesokan harinya dia bersedia memberikan jawabannya, dan menjadi awal dari hubungan antara guru dan murid yang sangat dekat.

Selamapengembaraannya mencariilmu Ibn Jinni bertemu dengan al-Mutanabbi sebanyak dua kali, sekali di Aleppo dan sekali lagi di Siraz pada masa Khalifah Shaif al-Daulah. al-Mutanabbi sangat menghormati Ibn Jinni karena dialah orang pertama yang menulis syara $\underline{h}$ (komentar) Dîwân al-Mutanabbi dalam dua syarah: alkabîr dan al-shaghîr.

Ibn Jinni dikenal sebagai salah seorang al-Nahwiyyin atau ahli Nahwu sekaligus ahli Ilmu Sharaf. Namun sepertinya dia lebih tertarik pada Ilmu sharaf, terbukti dengan keingintahuannya yang besar

Zamzam Afandi Abdillah. Ibn Jinni Menembus Sekat Mazhab Linguistik dalam Adabiyyat. Vol. 8. 2009, h. 55 tentang perubahan waw menjadi alif dalam beberapa kata Arab. Dalam pembahasannya Ibnu Jinni sama halnya denga al-Farisi, beraliran Bashrah meskipun dia belajar aliran Kûfah. Karena itu dia kadang-kadang juga mengutip pendapat al-Tsa'labiy dan alKisâ'i, tokoh aliran Kûfah atau sekali-kali mengemukakan pendapat aliran Baghdâd yang merupakan kombinasi aliran Bashrah dan Kûfah.

Di antara murid Ibnu Jinni yang termahsyur adalah: Abu al-Qasim alTsamaniy (w. 442 H), Ibnu Burhan Abu Ahmad'Abdal-Salâmal-Bashry(w.405H)dan Abu al-Hasan al-Samsamiy (w. 415 H). ${ }^{10}$

Ibnu Jinni wafat di Baghdad pada malam Jum'at bulan Safar, lalu dikuburkan di samping kuburan gurunya di Shuniziyah. Ibn Jinni meninggalkan tiga orang anak:' Ali, 'Âla dan 'Alâ. Menurut Yaqût al-Hamawi ketiga anak Ibnu Jinni mengikuti jejak ayah merekamenjadiahlibahasadansastrawanyang terkenal.

Ibn Jinni mewariskan banyak karya akademik di berbagai bidang, terutama linguistik. al-Khashâ'ish merupakan buku yang pertama kali dicetak dan diterbitkan oleh al-Hilal, Masir, tahun 1923. Meskipun buku tersebut belum meluas, namun pengaruhnya sagat besar di kalangan para ilmuwan, sastrawan, peneliti maupun pemakai bahasa Arab. ${ }^{11}$

Selain al-Khashâish, buku al-Numam juga sangat popular. Buku ini berisikan syairsyair ejekan. Buku ini merupakan syarah buku al-Syakiri (w. $275 \mathrm{H}$ ) diterbitkan di Eropa kemudian buku tersebut diberi judul kemudian dirubah lagi menjadi Kitâbi fi Dîwâni Hudzail kemudian berubah lagi menjadi al-Tamâm, sehingga 44.

10 Ibn Burhan Al-'Ukbary, Syarh al-Luma', h.

11 'Ikâwiy, Abâqirah al-Islam , h. 101-103 
buku ini tidak diterbitkan lagi.

Ada lagi karyanya yang tidak kalah terkenalnya yaitu kitab Sirr al-Shinâ'ah. Tulisan pada buku ini berupa manuskripmanuskrip. Banyak ilmuwan yang mengedit dan memberikan komentar terhadap buku tersebut kemudian mencetaknya seperti yang telah dilakukan oleh penulis buku Kasyf al-Zhunûn karya Abu Abbas bin Ahmad Muhammad al-Isybili yang terkenal dengan nama Ibn al-Hajj (w. 647 H). Karya intelektual Ibn Jinni secara lebih detil dapat dibaca dalam buku Mawsû'ah Abâqirat alIslâm tersebut.

\section{Dasar Teori Tentang Kajian Lafazh dan Makna}

Kajian makna tidak dapat dilepaskan dari kajian lafazh itu sendiri. Lafazh dan makna adalah dua unsur komunikasi yang senantiasa digunakan karena lafazh itu adalah perwujudan dari makna yang ingin disampaikanoleh sipembicara kepadalawan bicaranya. Akan tetapi, setiap lafazh tidak selalu mewakili makna yang sama setiap kali diucapkan. Begitupun suatu makna bisa diwakili oleh lafazh yang berbeda-beda pula sesuai dengan keberagaman si penutur, letak geografis, waktu pengucapan, dialek bahasa, dan sebagainya. Karena itu ketika mempelajari tentang lafazh dan makna, seorang hendaklah memperhatikan unsurunsur di atas seperti yang telah diisyaratkan oleh Ibn Jinni dalam bukunya al-Khashâ'ish bahwa tidak ada dua bahasa atau lebih yang persis sama.

Jikapun ada kata-kata yang sama pemakaiannya atau bersinonim, mestilah salah satu dari kata-kata tersebut lebih tinggi intesitas penggunaannya dan biasanya itulah kata asal. Sedangkan kata-kata yang lain adalah kata-kata yang kemudian kemungkinan bukan kata asli si pemakai bahasa tapi merupakan serapan dari bahasa ataupun dialek lain. Jadi dapat kita katakan bahwa menurut Ibn Jinni dua kata atau lebih yang bersinonim adalah kata-kata yang mempunyai padanan dan kemungkinan padanan pada dialek dan bahasa yang berbeda. ${ }^{12}$

Kata-kata yang bersinonim, menurut Ibn Jinni, adalah karena adanya proses asimilasi dan pertukaran kosa kata antarpenutur bahasa dengan dialek yang berbeda. Keberagaman lafazh untuk suatu makna ini membuat suatu bahasa lebih baik/lebih fleksibel dan menjadikannya sebagai bahasa universal serta sebagai alat komunikasi atau lingua franca bagi masyarakat secara umum. ${ }^{13}$

Sebuah kata, seperti disebutkan sebelumnya, bisa juga mempunyai dua makna atau lebih. Kata-kata seperti ini biasa diistilahkan dengan polisemi yang sepadan dengan musytarak lafzhî. Berbeda dengan ilmuwan Barat yang melihat polysemy dari bentuk bunyi ujaran-seperti kata pretty yang biasa berarti cantik, begitu atau banyak, tergantung siyâq kalamnya, maka Ibn Jinni melihatnya dari segi huruf dan harakat. Sebagi contoh adalah الصيدى yang berarti kondisi sangat kehausan bila dibaca al-shada, dan berarti gema/suara yang bersipongan apabila dihilangkan lam-nya dan dibaca $a s h d a .^{14}$

Berdasarkan uraian di atas, dapat ditegaskan bahwa pada dasarnya Ibn Jinni berpendapat bahwa makna adalah hasil akhir dari analisis menyeluruh terhadap peristiwa kebahasaan yang terjadi pada lafazh. Karena itu, dalam mempelajari

12 Ibn Jinni, al-Khashâ'ish 1, h. 372, Abd alKarim Mujahid, al-Dalâlah al-Lughawiyyah Inda AlArab, ('Amman: Dâr al-Dhiyâ, 1985), h. 102

13 Ibn Jinni, al-Khashâ'ish 1, h. 374

14 Ibn Jinni, al-Khashâ'ish 3, h. 93; Mujahid, AlDalâlah al-Lughawiyyah Inda Al-Arab, 114 
makna kita harus meninjau segala segi kebahasaan yang melingkupi konteks sosial, fonologis, morfologis, sintaksis dan leksikal. ${ }^{15}$

Walaupun demikian, kajian lafazh dan makna menurut Ibnu Jinni lebih ditekankan pada kajian fonologi, morfologi dan sintaksis sebagaimana telah diuraikannya di dalam Kitabnya al-Khashâish, tepatnya pada bab باب الدلالة اللفظية والصناعية والمعنوية. Secara harfiyah memang Ibn Jinni tidak menyebut kata fonem, morfem atau sintaksis sebagaimana yang dilakukan oleh para linguis kontemporer. Berikut sejumlah pemikiran linguistiknya tentang lafazh dan makna secara ringkas.

\section{1. al-Dalâlah al-Ijtimâ'iyah (Konteks Situasi)}

Dalam dalâlah Ijtima'iyah, makna mengacu kepada kontek situasi (siyâq al-kalâm) dan kondisi yang mengitari peristiwa kebahasaan. Kridalaksana mengartikan konteks situasi ini dengan lingkungan non-linguaistik yang menjadi alat untuk merinci ciriciri yang diperlukan untuk memahami makna ujaran. Dalam teori ini makna merupakan hubungan yang kompleks antara ciri linguistik ujaran dan ciri situasi sosial. ${ }^{16}$ Sebenarnya istilah konteks situasi ini sebelum Firth sudah dikenal di kalangan antropolog yang dipelopori oleh Malinowski. ${ }^{17}$

Mengingat pentingnya teori ini, Firth kemudian melengkapinya dengan konsep tentang asas-asas situasi

15 Firth, Papers in Linguistics: (Modes of Meaning), h. 142; Lih. Mujahid, Al-Dalâlah alLughawiyyah Inda Al-Arab, h. 157

16 Kridalaksana, Kamus Linguistik, 120

17 Pembahasan lebih mendalam tentang pendapat Malinowski ini bisa dilihat dalam Koenejaraningrat. Sejarah Teori Antropologi (Jakarta: UI press, 1987) 160; Mujahid, al-Dalâlah alLughawiyyah Inda Al-Arab, h. 158. peristiwa kebahasaan, yaitu :

a. Gejala-gejala yang erat kaitannya dengan para pemakai bahasa, baik pembicara maupun pendengar, yang menggambarkantentangsifatmereka secara lahir ataupun ekspresi yang bersumber dari kondisi kejiwaan mereka, yang mencakup, (i) kalimat si pemakai bahasa atau peristiwa penyampaian kalimat yang ada pada mereka, dan (ii) peristiwa di luar pembicaraan seperti perbuatan dan tingkah laku dan gerak-gerik atau body language/gesture.

b. Segala sesuatu yang berkaitan erat dengan sikap.

c. Pengaruh pembicaraan. ${ }^{18}$

Sebagai contoh, Ibn Jinni mengemukakan sya'ir Na'im ibnu alHarits ibnu Yazid al-Sa'dy :

$$
\text { تقول - وصكت وجهها - بيمينها ت ابعلي هذا بالرحى المتقاعس }
$$

Dalam bait sya'ir ini, menurut Ibn Jinni, terdapat konsep-konsep sebagai berikut:

a. Peristiwa pembicaraan/ peristiwa linguistis (al-ḥadats al-kalâmî) yaitu pada lirik kedua yang menceritakan tentang keheranan dan pengingkarannya (pelaku, perempuan).

b. Peristiwa non-linguistik (al-hadats ghair al-kalâmî) yaitu terdapat pada lirik pertama yang menggambarkan tentang situasi ketika pelaku berbicara.

c. Pengarus linguistis dan non-linguistis, yaitu ketika mendengar lirik pertama tanpa mengetahui situasi ketika pelaku berbicara, kita memahami keheranan dan pengingkaran si pelaku. Akan tetapi

18 Mujahid, Al-Dalâlah al-Lughawiyyah Inda AlArab, h. 158-159. 
akan lebih yakin lagi apabila diceritakan situasi ketika tamparan itu terjadi, serta akan menjadi lebih kuat kesannya ketika melihat langsung peristiwanya. ${ }^{19}$

Dalam penjelasannya tentang segala sesuatu yang berkaitan dengan sikap/situasi, Ibnu Jinni memberikan contoh sya'ir al-Walid ibnu 'Uqbah bin Abi Mu'ith: قلنا لها قفى قالت قاف Makna dalam bait di atas akan dapat dipahami jika diceritakan situasi yang menyertainya, yaitu :

$$
\begin{aligned}
& \text { قالت قاف ( و امسكت بزمام بغيرها ) } \\
& \text { أو (عاخنتاه علينا) }
\end{aligned}
$$

Peristiwa non-linguistis yang diceritakan و امسكت بزمام بغيرها berarti الوقوف. Dengan demikian hilanglah keraguanterhadap maknaujaransebagai jawaban atas permintaan dan bukan sebagai keheranan dan pengingkaran..$^{20}$

Selanjutnya untuk menjelaskan urgensi konteks situasi dalam pemaknaan, Ibn Jinni memberikan contoh

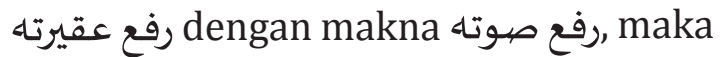
ini tidak akan dipahami tanpa melihat konteks situasinya.

Sedangkan pengaruh makna dan peran konteks situasi sebagai peristiwa linguistikdalam menggantikan peristiwa linguis dicontohkan oleh Ibn Jinni اضرب زئ زيدا dengan kata dengan makna , زيدا , makna ini akan dapat dipahami dengan memperhatikan konteks situasi (peristiwa non-linguistik) yaitu ketika kata زيدا diucapkan kepada seseorang yang sadang memegang pedang.

Karenanya bisa dikatakan bahwa Ibnu Jinni telah membedakan makna leksikal dengan makna sosial atau

19 Ibn Jinni, al-Khashâ'ish 3, h. 93; Mujahid, alDalâlah al-Lughawiyyah Inda Al-Arab, h. 114

20 Ibn Jinni, al-Khashâ'ish 3, h. 246, Mujahid, al-Dalâlah al-Lughawiyyah Inda Al-Arab, h. 162 konteks situasi meskipun ada linguist yang menyamakannya seperti Ibrahim Anis. ${ }^{21}$

\section{2. al-Dalâlah al-Shawtiyah (Phonology)}

Fonologi sebagai salah satu cabang linguistik adalah suatu ilmu yang mengkaji fungsi bunyi-bunyi dalam bahasa tertentu yang dapat membedakan makna suatu kata dengan yang lainnya. Makna fonologis ini bisa berbentuk fonem, strees (nabr) dan intonasi (tanghîm) ${ }^{22}$. Ibnu Jinni mengistilahkan al-dalâlah al-shawtiyah dengan al-dalâlah al-lafzhiyah yang merupakan dalâlah yang lebih dominan dari kedua dalâlah lainnya, yaitu aldalâlah al-shina'iyah dan al-dalâlah al-Maknawiyah. Sebagai contoh : kata قام yang terdiri dari huruf-huruf dan satuan-satuan bunyinya yaitu bunyi qaf, fathah thawîlah (madd), mim dan fathah, Dalâlah lafziyahnya mengandung arti berdiri atau قيام. Maksudnya, susunan قام قيام mengacu kepada makna قيام dalam arti bahwa dalam verba terkadang makna aksi. Akan tetapi, jika salah satu unsur satuan bunyinya diganti dengan huruf shad, sehingga bunyinya menjadi صام, maka sudah pasti maknanya berubah, karena ada fonem yang berbeda pada kedua kata tersebut. ${ }^{23}$

Ibn Jinni juga menjelaskan tentang perbedaan makna karena perbedaan fonem dalam satu kata, seperti kata sha'ida (صعد dengan shâd) yang berarti

21 Ibn Jinni, al-Khashâ'ish 3, h. 248,. Mujahid, al-Dalâlah al-Lughawiyyah Inda Al-Arab, h. 163

22 Moh. Matsna HS, Orientasi Semantik AlZamakhsyari, (Jakarta: Anglo Media, 2006), Cet. Ke-1, h. 76

23 Ibn Jinni, al-Khashâ'ish 3, h. 98-100, Mujahid, al-Dalâlah al-Lughawiyyah Inda Al-Arab, h. 167-168. 
naik tangga dan sa'ida (سعد dengan sin) yang berarti beruntung.

Berdasarkan unit-unit fonem, dalâlah shawtiyah ini dibedakan atas dua yaitu fonem terikat atau sagmental phonemis seperti contoh di atas, dan fonem bebas atau suprasegmental phonemes, seperti stress (nabr) dan intonasi (tanghîm).

Untuk mengetahui di mana letak stress pada suatu kata dalam bahasa Arab, perlu diketahui dulu jenis syllable atau suku kata dalam bahsa Arab. Ada lima syllable atau maqtha' di dalam bahasa Arab fush $\underline{h} \hat{a}$, yaitu:
1). CV ب (ص ح) seperti
2). CVV تُبْ (ص ح ح) (ص ح (ص) seperti)

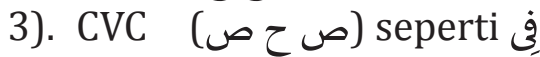

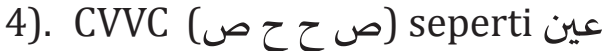
5). CVCC بنت seperti (ص ح ص ص حص)

Ket: $\mathrm{C}=$ consonant

$\mathrm{V}=$ vocal

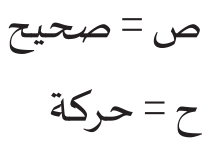

Untuk menentukan letak nabr/ stress dalam satu kata, para ahli berbeda pendapat. Sebagai contoh, menurut Dr. Ibrahim Anis, letak nabr dalam suatu kata bahasa Arab bias dilihat dari jenis suku kata atau syillable paling akhir dari kata tersebut. Bila suku kata terakhir itu berupa jenis keempat atau kelima (CVVC atau CVCC), maka di situlah letak nabrnya. Contoh: نستعين dan مستقر, عين nabrnya terdapat pada suku kata نمينق dan قرّ.

Apabila suku kata terakhir bukan dari jenis keempat atau kelima, dengan kata lain dia adalah jenis kedua dan ketiga (CVV atau CVC) maka di situlah letak nabrnya. Contoh: يستحيل dan
استَغْفْرْ pada suku kata حي dan تغ.

Apabila suku kata tersebut termasuk jenis pertama (CV), maka letak nabrnya ada pada suku ketiga dari akhir. Seperti kata maka nabrnya ada pada suku kata جَ. جَن

Sedangkan untuk tanghîm/ intonasi, hal ini disesuaikan dengan naik turunnya bunyi atau nada dalam sebuah kalimat sehingga merubah bentuk kalimat yang sekaligus juga merubah makna. ${ }^{25}$

\section{3. al-Dalâlah al-Sharfiyah (Morfologi)}

Morfologi adalah bagian linguistic yang mempelajari tentang morfem. Morfologi adalah satu didiplin ilmu yang mempelajari dan menganalisis struktur, bentuk dan klasifikasi kata-kata. Dalam kajian Bahasa Arab, morfologi dikenal dengan ilmu sharf. Morfologi juga didefinisikan sebagai berikut:

$$
\text { أصغروحدة لغوية ذات معنى فى لغة ما26 }
$$

"Unit bahasa terkecil yang memiliki makna"

Ibn Jinni menyebutnya al-Dalâlah al-Shinâ'iyah, yaitu yang dihasilkan dari satuan morfologis dalam kata. Sebagai contoh kata فتح, maka akan kita temukan derivasi/isytiqâq dari kata tersebut, diantaranya: يفتح، فاتح، dan lain sebagainya. Keseluruhan kata tersebut memiliki makna yang berbeda. Bila kita amati kata-kata tersebut, maka masingmasing terdiri atas dua unit bahasa

24 Moh. Matsna HS, Orientasi Semantik AlZamakhsyari, h. 78-79

25 Moh. Matsna HS, Orientasi Semantik AlZamakhsyari, h. 82

26 David Cristall, al-Ta'rif bi 'Ilm al-Lughah, Terjemahan Hilmi Khalil, (Kairo: al-Hai'ah alMishriyah al-'Āmmah, 1979), h. 162 
yang memiliki arti atau morfem, yaitu morfem dasar yang disebut morfem bebas (free morpheme/morfem hurr) dan morfem tambahan yang disebut dengan morfem terikat (bound morpheme/morfem muqayyad).

Morfem muqayyad atau morfem terikat terbagi menjadi dua, yaitu ${ }^{27}$ :

1). Derivasional morphem (morfem isytiqâqiy) atau morfem derivasi yaitu morfem berupa tambahan/ ziyâdah atau perubahan yang terdapat pada fi'il mujarrad. Seperti:
a). - قتل - يقتل - قَتلة - قِتلة - قاتل مقتول ...الخ
b). قتل - قاتل - تقاتل - اقتتل
c). - علم - أعلم - عالم - تعلّم استعلم

2. Inflecting morphemes/morfem I'rabiy atau morfem infleksi yaitu morfem berupa tambahan yang ada pada fi'il, ism atau kata sifat/syibh al-shifah berupa i'râb, baik berupa i'râb huruf maupun i'râb harakat. Jadi, morfem i'râbî ini terkait erat dengan masalah ilmu nahwu. Sebagai contoh:

$$
\begin{aligned}
& \text { • الفعل : كتب - كتبا - كتبوا - كتبت - } \\
& \text { كتبتا - كتبن ... الخ } \\
& \text { • الاسـم : سيّارة - سيّارتان - سيّارات } \\
& \text { • الصفة : عالم - عالمان - عالمون - عالمة } \\
& \text { - عالمتان - عالمات }
\end{aligned}
$$

Dalâlahiniberkaitan dan bergantung kepada dalâlah sebelumnya. Dari segi tingkatan, dalâlah ini lebih rendah/

27 Moh. Matsna HS, Orientasi Semantik AlZamakhsyari, h. 84-85 lebih lemah dari dalâlah shawtiyyah baik secara lisan maupun tulisan. Pada contoh kata qama di atas, Dalâlah shinâ'iyah-nya adalah masanya, yaitu yang telah lalu/mâdhî.

Ibnu Jinni juga mengemukakan peran penting sebuah morfem dalam pemaksaan suatu kata. Umpamanya hurufmudhâra'ah selain berfungsiuntuk menjadikan kata bermakna hâl (present) dan istiqbâl (future), juga berfungsi untuk melambangkan fâ'il atau pelaku. Begitu pula afiksasi, perubahan vokal dan prose-prose morfologis lainnya akan membawa perubahan makna.

\section{4. al-Dalâlah al-Nahwiyah (Syntax)}

Sintaksis, disebut juga gramatika atau kaidah bahasa. Menurut R. R. K. Hartmann dan F. C. Stork, sintaksis adalah "Syintax is the Branch of grammar which is conserned with the study of the arrangement of words in sentences and of the means by which such relationship are shown, e.g. word order or inflection." ${ }^{28}$

Dari definisi tersebut, dapat dipahami bahwa sintaksis merupakan bagian dari grammar/kaidah bahasa yang mengkaji tentang posisi\&makna sebuah kata di dalam sebuah kalimat sempurna. al-Dalâlah al-Nahwiyah atau al-Dalâlah al-Ma'nawiyah adalah makna yang dihasilkan oleh tingkatan yang lebih rendah dari al-Dalâlah alSharfiyah. Pada contoh yang sama: qâma, dalâlah ma'nawiyahnya adalah pelakunya: huwa, orang ketiga tunggal/ dia laki, karena setiap fi'il mesti mempunyai fâ'il.

28 R. R. K. Hartmann dan F. C. Stork, Dictionary of Language and Linguistics, (London: Applied Science Publishers Ltd, 1972), h. 231 
Mengenai dalâlah nahwiyah ini, Ibn Jinni membedakan antara makna nahwi (grammatical meaning) dengan makna mu'jamî (lexical meaning). Sebagai contoh, Ibn Jinni mengemukakan bahwa menurut ahli nahwu, semua fâ'il itu $r a f a '$ dan maf'ûl itu nashab. Padahal dalam pemakaiannya tidak selalu demikian. Karena fâ'il dan maf'ûl menurut arti hakiki atau menurut arti leksikal tidak harus dibaca rafa' dan nashab. Seperti yang terdapat dalam contoh-contoh berikut: $^{29}$

$$
\begin{aligned}
& \text { 1) ضُرِبَ زيدّ } \\
& \text { 2). إن زيداً قام } \\
& \text { 3). عجبت من قيام زيدٍ }
\end{aligned}
$$

Jika diperhatikan pada contoh kalimat pertama, kata Zayd-nya marfu' padahal secara hakiki, kata tersebut berfungsi sebagai obyek penderita (yang dipukul). Sedangkan Zayd pada kalimat kedua dibaca manshub meskipun dia adalah fấil (pelaku). Begitu juga dengan Zayd yang ketiga yang dibaca majrur padahal pada hakikatnya dia adalah $f a ̂$ 'il (pelaku).

\section{Simpulan}

Dari uraian di atas dapat disimpulkan bahwa teori makna dalam pemikiran linguistik Ibn Jinni didasarkan kepada proses-proses yang terjadi pada lafazh sesuai dengan konteks situasi atau makna sosial, makna fonologis, morfologis, sintaksis dan makna leksikal. Makna bahasa Arab adalah hasil akhir dari analisis menyeluruh terhadap peristiwa kebahasaan yang terjadi pada lafazh yang meliputi: al-dalâlah al-

29 Mujahid, Al-Dalâlah al-Lughawiyyah Inda AlArab, h. 199-200 ijtimâ'iyyah (konteks situasi), al-dalâlah alshawtiyyah, al-dalâlah al-sharfiyyah, dan aldalâlah al-nahwiyyah (makna nahwi, makna sintaksis)

Namun demikian, pemikiran linguistik Ibn Jinni tentang lafazh dan makna lebih ditekankan pada kajian fonologi, morfologi dan sintaksis dalam bingkai penggunaan bahasa Arab sebagai media komunikasi, baik lisan maupun tulisan. Secara harfiyah, Ibn Jinni tidak menyebut istilah fonem, morfem atau sintaksis sebagaimana yang dilakukan oleh para linguis kontemporer, karena istilah linguistik saat itu adalah istilah-istilah Arab tersebut. Pemikiran linguistik Ibn Jinni penting dikembangkan dalam proses pembelajaran 'ilm aldalâlah untuk memperkaya substansi dan metodologi kajian semantik bahasa Arab di masa mendatang. []

\section{Daftar Rujukan}

Abdillah, Zamzam Afandi. "Ibn Jinni Menembus Sekat Mazhab Linguistik", dalam Jurnal Adabiyyat. Vol. 8. 2009.

Cristall, David, al-Ta'rîf bi 'Ilm al-Lughah, Terjemahan Hilmi Khalil, Kairo: alHai'ah al-Mishriyah al-'̂̂mmah, 1979.

Djajasudarma, T. Fatimah, Semantik 1: PengantarkeArah Ilmu Makna, Bandung: Erasco, 1993.

Firth, JR., Papers in Linguistics: (Modes of Meaning), Oxford: Oxford University Press, 1957.

Halim, Najjar, Târîkh al-Adab al-Arabî,, Jilid II, Kairo: Dâr al-Ma'ârif, tt.

Hartmann, R. R. K., dan Stork, F. C., Dictionary of Language and Linguistics, London: Applied Science Publishers Ltd, 1972. 
Ibn Jinni, al-Khashâ'ish Jilid 1-3. Kairo: Matba'ah Dâr al-Kitâb al-Mishriyah, 1952 M.

'Ikawi, Rihab Khudar, Mawsû'ah Abâqirat Al-Islam: al-Nahwi wa al-Lughah wa alFiqh, Beirut: Dâr al-Fikr al-'Arabî, 1993.

Koenejaraningrat, Sejarah Teori Antropologi, Jakarta: UI Press, 1987.

Kridalaksana, Harimurti, Kamus Linguistik, Jakarta: Gramedia, 1993.

Matsna HS, Moh., Orientasi Semantik alZamakhsyari, Jakarta: Anglo Media, Cet. I, 2006.
Mujahid, Abd al-Karim, al-Dalâlah alLughawiyyah 'Inda al-Arab, 'Amman: Dâr al-Dhiyâ' 1985.

Tarigan, Henry Guntur, Pengajaran Semantik, Bandung: Angkasa, 1995.

'Ukbari, Ibn Burhan, Syarh al-Luma', Kuwait: al-Silsilat al-Turâtsiyyah, Cet. ke-1, 1994. 